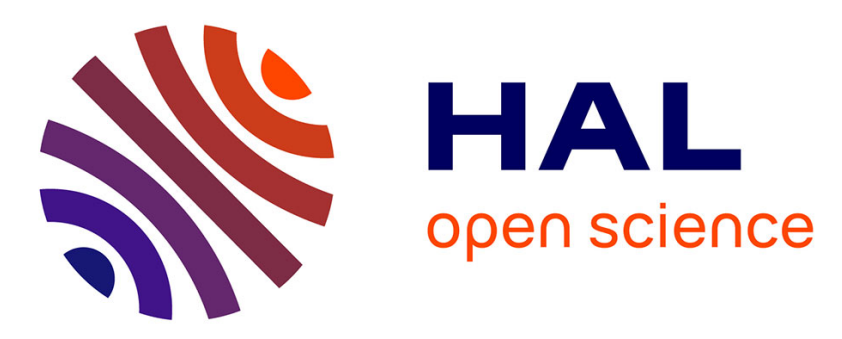

\title{
Re-delimitation of Tinospora (Menispermaceae): Implications for character evolution and historical biogeography
}

Lian Lian, Rosa del C. Ortiz, Florian Jabbour, Zhi-duan Chen, Wei Wang

\section{- To cite this version:}

Lian Lian, Rosa del C. Ortiz, Florian Jabbour, Zhi-duan Chen, Wei Wang. Re-delimitation of Tinospora (Menispermaceae): Implications for character evolution and historical biogeography. Taxon, 2019, 68 (5), pp.905-917. 10.1002/tax.12126 . hal-02612852

\section{HAL Id: hal-02612852 \\ https://hal.science/hal-02612852}

Submitted on 19 May 2020

HAL is a multi-disciplinary open access archive for the deposit and dissemination of scientific research documents, whether they are published or not. The documents may come from teaching and research institutions in France or abroad, or from public or private research centers.
L'archive ouverte pluridisciplinaire HAL, est destinée au dépôt et à la diffusion de documents scientifiques de niveau recherche, publiés ou non, émanant des établissements d'enseignement et de recherche français ou étrangers, des laboratoires publics ou privés. 


\title{
Re-delimitation of Tinospora (Menispermaceae): Implications for character evolution and historical biogeography
}

\author{
Lian Lian ${ }^{1,2}$, Rosa Del C. Ortiz ${ }^{3}$, Florian Jabbour ${ }^{4}$, Zhi-Duan Chen ${ }^{1}$, Wei Wang ${ }^{1,2}$ \\ 1 State Key Laboratory of Systematic and Evolutionary Botany, Institute of Botany, Chinese Academy of \\ Sciences, Beijing \\ 100093, China \\ 2 University of Chinese Academy of Sciences, Beijing 100049, China \\ 3 Missouri Botanical Garden, 4344 Shaw Blvd., St. Louis, Missouri 63110, U.S.A. \\ 4 Institut Systématique, Evolution, Biodiversité (ISYEB), Muséum national d'Histoire naturelle, CNRS, \\ Sorbonne Université, Université des Antilles, EPHE, 57 rue Cuvier, CP39, Paris 75005, France
}

Address for correspondence: Wei Wang, wangwei1127@ibcas.ac.cn

DOI https://doi.org/10.1002/tax.12126

\begin{abstract}
Traditional Tinospora is a heterogeneous genus, distributed in the African and Asian tropics as well as Australia and adjacent islands. Molecular phylogenetics has contributed greatly to improve our understanding of the genus over the past decade, however its circumscription is yet unresolved. In this study, we present a phylogenetic analysis of Burasaieae using six molecular markers (rbcL, atpB, matK, ndhF, trnL-F, ITS), with a focus on Tinospora. Our results indicate that sampled species of Tinospora are distributed in three different clades. Tinospora tinosporoides, endemic to Australasia, is strongly supported as sister to the South American Borismene. By integrating lines of evidence frommolecular phylogeny andmorphology, we resurrected themonotypic Fawcettia to include F. tinosporoides. Our estimated age for the split of Fawcettia-Borismene was ca. $29 \mathrm{Ma}$, suggesting that trans-Pacific long-distance dispersal may be the most feasible explanation for the Australasian-South American disjunction. Tinospora oblongifolia is a member of Hyalosepalum, characterized by three stamens with connate filaments, whereas T. tenera, once placed in Hyalosepalum, is recovered within Tinospora, characterized by six stamens. Evolutionary inferences of morphological characters indicate that the five selected characters, traditionally used to distinguish genera in Burasaieae, are highly homoplastic. Our molecular dating and ancestral range reconstruction suggest that Tinospora originated from Africa in the middle Oligocene (ca. $28 \mathrm{Ma}$ ) and expanded into Asia in the Early Miocene (ca. $21 \mathrm{Ma}$ ). Within Tinospora, a vicariance event occurred in the Middle Miocene (ca. $17 \mathrm{Ma}$ ) resulting in the split of African T. tenera and its Asian allies. One dispersal fromAsia toAfricawas inferred in the LateMiocene (ca. $10 \mathrm{Ma}$ ). Australian T. smilacina and T. esiangkara originated from Asia in the early Late Miocene (ca. $11 \mathrm{Ma}$ ). Thus, geodispersal and subsequent vicariance, as well as transoceanic long-distance dispersal, have been responsible for the present distribution of Tinospora.
\end{abstract}

Keywords biogeography; Fawcettia; geodispersal; Menispermaceae; phylogeny; tropical forests

\section{INTRODUCTION}

The genus Tinospora Miers (Menispermaceae), consisting of about 32 species, is disjunctly distributed in the African and Asian tropics, also in Australia and adjacent islands (Forman, 1986, 2007; Kessler, 1993). Tinospora species are main foodplants of larvae of fruit-piercing moths, and thus play an important role in the biological chain that results in extensive damage to certain fruit crops, such as longan, citrus, and mandarin (Bänziger, 1982). Some species, such as T. crispa (L.) Hook.f. \& Thomson, T. sinensis (Lour.) Merr., and T. sagittata Gagnep. (= Paratinospora sagittata (Oliv.) Wei Wang), are utilized

as traditional Chinese medicines (Luo, 1996). Nevertheless, traditional Tinospora is a heterogeneous assemblage. Based on molecular phylogenetic analyses, at least four species have been segregated from the genus. Tinospora caffra (Miers) Troupin (= Desmonema caffra Miers) was the first to be found not to cluster with other Tinospora (Ahmad \& al., 2009; Hoot \& al., 2009; Jacques \& al., 2011; Wefferling \& al., 2013; Ortiz \& al., 2016). Wang \& al. (2017) confirmed this result and resurrected Hyalosepalum Troupin to accommodate $H$. caffrum (Miers) Troupin (= T. caffra). Tinospora sagittata Gagnep. (= Paratinospora sagittata (Oliv.) Wei Wang) and T. dentata Diels (= Paratinospora dentata (Diels) Wei Wang) were excluded from Tinospora and placed into the newly described genus Paratinospora Wei Wang (Wang \& al., 2017). Tinospora uviforme (Baill.) Troupin 
was recovered as a member of Chasmanthera Hochst., i.e., C. uviformis Baill. (Ortiz \& al., 2016). On the other hand, Limacia esiangkara F.M.Bailey was transferred to Tinospora by Forman (2007) as T. esiangkara (F.M.Bailey) Forman, and this placement was confirmed by subsequent molecular studies (Ortiz \& al., 2007; Wang \& al., 2012, 2017). Although tremendous progress has been made in our understanding of Tinospora over the past ten years, its circumscription has remained unresolved, mainly owing to the uncertain systematic position and taxonomic treatment of Fawcettia F.Muell.

Fawcettia with the sole species F. tinosporoides F.Muell. was first described by Mueller (1877) and was thought to be close to Fibraureae or Tinospora of Burasaieae. The genus was recognized by Bailey (1899) and was retained by Diels (1910) in his monograph of the family Menispermaceae, on the basis of the presence of a third whorl of outermost sepals. However, Forman (1981) argued that the presence of this third outermost whorl of sepals was not only inconsistent in Fawcettia, but that the difference in sepal whorls was too small to justify the recognition of the latter and therefore placed it in Tinospora as T. tinosporoides (F.Muell) Forman. Subsequent authors accepted its inclusion in Tinospora (Kessler, 1993; Forman, 2007; Mabberley, 2017). Tinospora tinosporoides is restricted to rainforests and complex notophyll vine forests in southeastern Queensland and northeastern New South Wales (Forman, 2007), and to date, this species has not been sampled in any molecular study.

Tinospora together with Chasmanthera Hochst. and Jateorhiza Miers was placed in a broad Chasmanthera by Baillon (1872). However, this broad Chasmanthera was not accepted by subsequent authors (e.g.,Diels, 1910; Troupin, 1962; Kessler, 1993). Troupin (1962) argued, if Baillon' s concept was adopted, Kolobopetalum Engl., Leptoterantha Louis ex Troupin, and Syntriandrium Engl. should also be reduced to the broad Chasmanthera. Similarly, Odontocarya Miers could also be placed in the broad Chasmanthera (Barneby, 1970). Sepals and stamens are considered the most important characters in keeping these genera separate (Troupin, 1962), yet to date, their taxonomic significance has never been discussed in comparison to molecular phylogeny. Recent phylogenetic analyses indicate that the aforementioned seven genera, as well as Dialytheca Exell\&Mendonça, Hyalosepalum, Rhigiocarya Miers, and Sarcolophium Troupin, formed a monophyletic group with strong support (e.g., Wang \& al., 2012, 2017; Ortiz \& al., 2016). To shed light on the taxonomic status of these genera, the evolutionary patterns of some taxonomically relevant morphological characters, such as number of sepal whorls, stamen connation, and pollen aperture types (Diels, 1910; Troupin, 1962; Kessler, 1993), need to be evaluated in a broad phylogenetic context.

The objectives of this study are: (1) to re-delimitate Tinospora by clarifying the phylogenetic position and taxonomic treatment of Fawcettia, (2) to determine the evolutionary patterns of key morphological characters of Burasaieae, and (3) to investigate the historical biogeography of Tinospora s.str.

\section{MATERIALS AND METHODS}

\section{Taxon sampling and DNA sequencing}

We sampled 44 species, representing 22 of the 24 currently recognized genera in Burasaieae (Ortiz \& al. 2016), and Paratinospora and Hyalosepalum recently described and resurrected by Wang \& al. (2017), respectively. Our sampling includes 16 species still placed in Tinospora, 3 from Africa, 4 from Australasia, and 9 from Asia. Following the results of Wang \& al. (2012) and Ortiz \& al. (2016), we selected three species representing all three genera of Coscinieae, the other tribe of Chasmantheroideae, as outgroups. Species, vouchers and GenBank accession numbers are given in the Appendix 1.

We amplified six plastid (rbcL, atpB, matK, ndhF, trnL-F) and nuclear (ITS) markers. Laboratory procedures and sequence handling followed Wang \& al. (2017). When ITS-A and ITS-B did not work for long ITS sequences, additional primers, ITSC and ITS-D, were used (Blattner, 1999). Sequences were aligned using Geneious v.10.1.3 (Kearse \& al., 2012) based on the previous data matrices of Wang \& al. (2017), and then adjusted manually in BioEdit v.7.0 (Hall, 1999). One polyAG region in the trnL-F matrix (representing 10 nucleotides) and four difficult-to-align regions in the ITS matrix (encompassing

126 nucleotides) were excluded from the analyses. The final lengths of these six marker datasets were: rbcL, 1385 bp; atpB, 1412 bp; matK, 1235 bp; ndhF, 2066 bp; trnL-F, 1133 bp; and ITS, 656 bp (suppl. Appendices S1-S6).

\section{Phylogenetic analysis}


Phylogenetic analyses were conducted using maximum likelihood (ML) and Bayesian inference (BI) methods for the combined cpDNA (five plastid markers), ITS, and the combined cpDNA and ITS datasets. ML and BI analyses were conducted in RAxML v.7.2.6 (Stamatakis, 2006) and MrBayes v.3.2.5 (Ronquist \& al., 2012), respectively. For ML analyses, RAxML was performed with the GTR + I + $\Gamma$ substitution model for each DNA region, and nodal support was assessed using the fast bootstrap option with 1000 replicates. For BI analyses, each DNA region was assigned its own model of nucleotide substitution, as determined by the Akaike information criterion (AIC) via jModeltest v.2.1.4 (Posada, 2008). Two independent runs, each consisting of fourMarkov ChainMonte Carlo (MCMC) chains, were conducted with one tree sampled for every 1000 generations over 50 million generations, starting with a random tree. Stationarity was determined in Tracer v.1.6 (Rambaut \& al., 2014). Majority-rule (>50\%) consensus trees were constructed after removing the burn-in period samples (the first $25 \%$ of sampled trees). Based on Wang \& al. (2014), we used the thresholds BS $\geq 70 \%$ and $\mathrm{PP} \geq 0.95$ as an indication of significant conflict between the cpDNA and ITS datasets.

\section{Analysis of character evolution}

The distribution of five morphological characters, upon which the generic classification of Burasaieae, especially the broad Chasmanthera has traditionally been based, was investigated. Orthogynium sp. and Tinospora sp. were excluded from the analyses because the five characters evaluated here are still unknown in these two taxa. Information on morphological features was taken from the literature, particularly Diels (1910), Troupin (1962), Barneby (1970), Forman (1981), and Kessler (1993) for general morphological characters, and Thanikaimoni \& al. (1984) for pollen aperture types. Patterns of evolution were inferred using the ML approach as implemented in Mesquite v.2.75 (Maddison \& Maddison, 2011). The Markov k-state one-parameter model of evolution for discrete unordered characters (Lewis, 2001) was used.

\section{Molecular dating analysis}

We estimated the divergence times of Burasaieae using the uncorrelated lognormal Bayesian method in BEAST v.2.1.3 (Drummond \& al., 2012). Following Wang \& al. (2017), we used the cpDNA data for age estimates owing to the potential problems of recombination, incomplete concerted evolution, and high homoplasy in ITS sequences. Phylogenetic analyses (Ortiz \& al., 2016; Wang \& al., 2017; this study) indicate that the species of Tinospora are distributed in at least five clades. Thus, we did not use T. excavata Reid \& Chandler from the Paleocene-Eocene transition of eastern Belgium (Fairon- Demaret \& Smith, 2002) as a calibration point, as it is not possible to place it in the phylogenetic tree. Herewe selected three fossils that can confidently be placed in our tree as internal calibration points. (1) A fossil endocarp of Anamirta Colebr. was used to constrain its stem age to at least 43.7 Ma (Manchester, 1994). (2) The stem age of Parabaena Miers was constrained to be at least 47.8 Ma based on the fossil Parabaena bognorensis Chandler from the London Clay (Chandler, 1964). (3) The stem group age of Jateorhiza was also constrained to be at least $47.8 \mathrm{Ma}$ based on the fossil Jateorhiza gilliami Chandler (Chandler, 1964). Following the suggestion of Parham \& al. (2012), we used the uniform prior distributions for these three fossil calibration points. We set a $101 \mathrm{Ma}$ maximum age for the root, which is the estimated crown age of the Chasmantheroideae (Wang \& al., 2012), with a normal distribution and a standard deviation of three. A recent study reported a relatively younger age $(80.14 \mathrm{Ma})$ for the crown age of the subfamily (Wefferling \& Hoot, 2018). To explore the impact of the root age on the estimates, we also constrained the root to $80.14 \mathrm{Ma}$ and reran the dating analysis using the cpDNA data.

Both dating analyses were carried out under the GTR $+\mathrm{I}+\Gamma$ model for each marker partition separately and with a Yule tree prior. The MCMC chains were run for 50 million generations, sampling every 5000 generations. Appropriate burn-in and the effective sample size value of each parameter $(>200)$ were assessed in Tracer v.1.6 (Rambaut \& al., 2014). The maximum clade credibility (MCC) tree with median branch lengths and $95 \%$ highest posterior density (HPD) intervals on nodes was built in TreeAnnotator v.1.8.4 (Drummond \& al., 2012).

\section{Biogeographical analysis}

To infer range evolution of Tinospora, we focused on Tinospora and its closely related genera belonging to the broad Chasmanthera. The MCC tree obtained from the cpDNA data with the root set as 101 Ma was modified in Mesquite v.2.75 (Maddison \& Maddison, 2011) and was accordingly used for biogeographical analysis in the R package BioGeoBEARS (Matzke, 2013). Following Ree \& Sanmartín (2018), we used the dispersalextinctioncladogenesis (DEC) model (Ree \& Smith, 2008). Four major areas of distribution were categorized: Asia (A); Australasia (B); Africa (C); and South America (D). We allowed the inferred ancestors to occupy up to two areas (sampled tips occupy only one area). Dispersal probabilities between pairs of areas were specified based on Buerki \& al. (2011).

\section{RESULTS}




\section{Phylogenetic analyses}

The cpDNA dataset comprised 7235 aligned nucleotides. ML and BI analyses yielded identical trees (Fig. 1). Calycocarpum Nutt. ex Torr. \& A.Gray is the earliest-diverging lineage in Burasaieae, followed by the monophyletic group consisting of Aspidocarya Hook.f. \& Thomson, Disciphania Eichler, and Parabaena , and then Tinomiscium Miers ex Hook.f. \& Thomson. Tinospora tinosporoides and Borismene Barneby formed a clade with strong support ( $\mathrm{BS}=95 \%, \mathrm{PP}=1.0$ ). Dioscoreophyllum Engl. is sister to the broad Chasmanthera $(\mathrm{BS}=100 \%, \mathrm{PP}=1.0)$. Jateorhiza is sister to all other broad Chasmanthera $(\mathrm{BS}=100 \%, \mathrm{PP}=1.0)$. Tinospora (excluding T. oblongifolia and T. tinosporoides) is sister to the clade I $(\mathrm{BS}=90 \%, \mathrm{PP}=1.0)$. Tinospora oblongifolia (Engl.) Troupin is recovered as sister of Hyalosepalum $(\mathrm{BS}=72 \%$, PP $=0.96$ ). Rhigiocarya groups with Sarcolophium $(\mathrm{BS}=97 \%$, PP $=1.0)$. Relationships among the seven clades, Borismene-Tinospora tinosporoides, Paratinospora, Penianthus longifolius, Penianthus patulinervisSphenocentrum jollyanum, Burasaia Thouars-Orthogynium Baillon, Fibraurea Lour., and Dioscoreophyllumbroad Chasmanthera are not resolved.

The aligned matrix of ITS sequences was 657 characters in length. ML and BI analyses produced identical trees (Fig. 2). Comparing to the cpDNA topology, the ITS topology has lower resolution, but a distant relationship between Tinospora oblongifolia and other Tinospora is also recovered. Tinospora is sister to clade II (BS $=92 \%$, $\mathrm{PP}=1.0)$. Rhigiocarya and Kolobopetalum have a sister relationship with strong support $(\mathrm{BS}=90 \%, \mathrm{PP}=0.99)$.

The combined cpDNA and ITS dataset comprised 7892 aligned nucleotides. ML and BI analyses resulted in highly congruent trees (suppl. Fig. S1). The topology from the combined cpDNA and ITS dataset (suppl. Fig. $\mathrm{S} 1$ ) is congruent with the cpDNA tree (Fig. 1), but the relationships within Burasaieae are usually resolved with greater support in the combined cpDNA and ITS tree except for the placement of Rhigiocarya (the BS and PP values were $35 \%$ and 0.02 lower, respectively).

\section{Character evolution}

A summary of character states that are relevant for the taxonomy of the group is shown in Fig. 3. Exploration of character changes and ancestral-state inference were undertaken using the tree from the combined cpDNA and ITS analysis. The ML tree was chosen based on its congruence with that obtained from BI (suppl. Fig. S1).

Likelihood inferences of character states indicate that all five selected morphological characters (number of sepal whorls, number of stamens, stamen connation, dehiscence types of anthers, pollen aperture types) are homoplastic in Burasaieae. For example, three sepals seem to have evolved independently at least three times (Fig. 4A). Trace of the three states for stamen connation (no, yes, and outer whorl free and inner whorl connate) appears to be extremely complex (Fig. 4B).

\section{Divergence time estimation and biogeographical reconstruction}

The different ages of the root have no effect on divergence time estimates. A comparison of estimated times from the different ages of the root is shown in Fig. 5. The age estimation using the cpDNA data with the root set as $101 \mathrm{Ma}$ is here reported and was used for biogeographical analysis. Ancestral area reconstruction for Tinospora is indicated in Fig. 6. The Australian T. tinosporoides split from its South American sister Borismene at about 29.05 Ma (95\% HPD: 12.43-47.44; node 1 in Fig. 5). Tinospora originated from Africa at 28.57 Ma (95\% HPD: 22.67-34.76; node 2), and its most recent common ancestor had already spread to Asia by 21.54 Ma (95\% HPD: 15.63-27.62; node 3). A vicariance event separated African T. tenera Miers and its Asian sister at about 17.53 Ma (95\% HPD: 12.02- 23.39; node 4). One dispersal from Asia to Australia occurred at about 11.16 Ma (95\% HPD: 7.15- 15.92; node 5). The African T. bakis (A.Rich.) Miers diverged from the ancestor of the Australian T. esiangkara and T. smilacina Benth. at about 9.71 Ma (95\% HPD: 5.84- 14.61; node $6)$.

\section{DISCUSSION}

The trees resulting from the combined cpDNA and ITS dataset are congruent with those from the cpDNA dataset (suppl. Fig. S1 vs. Fig. 1), whereas the placements of Tinospora and Rhigiocarya are incongruent in the cpDNA and ITS trees (suppl. Fig. S2). The BS value the placement of Tinospora was increased from $90 \%$ in the cpDNA data to $100 \%$ in the combined cpDNA and ITS data. A similar case for Tinospora was also reported by Wang \& al. (2017). Based on statistical tests, Wang \& al. (2017) suggested that the conflict for the placement of Tinospora between the cpDNA and ITS data is artificial and resulted from high substitution rates and homoplasy in the ITS sequences. However, other causes, such as intergeneric hybridization or incomplete lineage sorting, cannot be ruled out. More nuclear DNA regions are needed to test these hypotheses in the future. For Rhigiocarya, the BS and PP values become lower in the combined cpDNA and ITS tree (Fig. 2 vs. suppl. Fig. $\mathrm{S} 1$ ). In the cpDNA tree, Rhigiocarya is sister to Sarcolophium, with which it shares longitudinally dehiscent 
anthers and pollen with tricolporate aperture. Conversely, the ITS data suggest Rhigiocarya as sister to Kolobopetalum, supported by outer free and inner connate stamens. Thus, Rhigiocarya might be a hybrid genus.

The intergeneric relationships within Burasaieae revealed by the cpDNA and combined cpDNA and ITS datasets are consistent with previous molecular studies (Wang \& al., 2012, 2017; Wefferling \& al., 2013; Ortiz \& al., 2016). As shown by Wang \& al. (2017), the topology was consistent with the separation of Paratinospora, Hyalosepalum, and T. uviforme from Tinospora. Moreover, we found that the Tinospora species sampled in this study are distributed in three different clades (Fig. 1, suppl. Fig. S1): Tinospora tinosporoides and Borismene formed a clade; T. oblongifolia clustered with Hyalosepalum; and the remaining Tinospora species formed a clade.

\section{The resurrection of Fawcettia and the Australasian-South American disjunction}

Because a third, outermost whorl of sepals is sometimes found in three Tinospora species, T. cordifolia (Willd.) Miers ex Hook.f. \& Thomson (sampled in this study), T. merrilliana Diels, and T. trilobata Diels, Forman (1981) reduced the monotypic Fawcettia to Tinospora, where it was placed as T. tinosporoides. However, our phylogenetic analyses strongly suggest that T. tinosporoides has only a distant relationshipwith Tinospora s.str. (including T. cordifolia, the type of the genus; Fig. 1). Besides the difference in number of sepal whorls, T. tinosporoides markedly differs from other Tinospora species in having triangular to ovate leaves without glandular patches below the basal nerve-axils (vs. cordate or linear leaves with glandular patches), pseudopaniculate inflorescences (vs. racemose), sessile male flowers (vs. pedicellate), densely spinulose endocarp (vs. verrucose or tuberculate), continuous, not ruminate endosperm (vs. ruminate; continuous endosperm also occurs in the New Guinean T. arfakiana Becc., a species not sampled here) (Forman, 1981, 2007), and pollen with tricolpate aperture (vs. tricolporate) (Figs. 3, 4). The sister relationship between Tinospora tinosporoides and Borismene is strongly supported $(\mathrm{BS}=95 \%, \mathrm{PP}=1.0)$. They share a three-whorled calyx (Fig. 3). Nevertheless, T. tinosporoides is distinguished from Borismene in many other morphological characters, such as inflexed petals (vs. not inflexed), carpophore present (vs. absent), papery endocarps with a smooth surface (vs. bony, densely spinulose), not ruminate endosperm (vs. ruminate), and tricolpate aperture (vs. tricolporate) (Barneby, 1972; Forman, 1981; Thanikaimoni \& al., 1984). Thus, our analysis suggests that Fawcettia is a distinct genus in Burasaieae and is here resurrected.

The sister relationship between Fawcettia and Borismene recovered in this study results in an AustralasianSouth American genus pair. This amphi-Pacific tropical disjunction in the Southern Hemisphere is fascinating as it results in an explanatory challenge, and may shed light on the assembly of tropical floras in the past (Thorne, 1972; Givnish \& Renner, 2004). Both Fawcettia and Borismene are restricted to tropical forests (Barneby, 1972; Forman, 2007). Our divergence time estimates indicate that the split of Fawcettia and Borismene occurred in the middle Oligocene, ca. 29 Ma (12.43-47.44 Ma; node 1 in Fig. 5). This estimated age is partly consistent with the opening of the Drake Passage between South America and Antarctica (ca. 30- 35 Ma; Sáez \& al., 1999; McLoughlin, 2001). It has been suggested that Antarctica may have served as a migration route for some megathermal lineages between Australasia and South America in the early Tertiary (Morley, 2003; Vicente \& al., 2017). However, during the Oligocene, global climate was cooling (Zachos \&al., 2001), which could have prevented migration of Menispermaceae through Antarctica. Molecular phylogenetic studies have indicated thatmigrations of megathermal lineages, such as Sapotaceae (Bartish \& al., 2011), Loranthaceae (Liu \& al., 2018), and Anomospermeae (Menispermaceae; Lian \& al., 2019), through Antarctica mainly occurred in the Paleocene- early Eocene, a global warming period (Zachos \& al., 2001). Thus, we hypothesize that trans-Pacific long-distance dispersal may explain the modern disjunct distribution of Fawcettia and Borismene. Fruits of both genera are red and fleshy drupes and may be favored by birds (Barneby, 1972). Trans-Pacific long-distance dispersal has been reported in some lineages, such as Coriaria L. (Coriariaceae; Yokoyama \& al., 2000), Nothofagus Blume (Nothofagaceae; Knapp \& al., 2005), and Heterozostera nigricaulis J.Kuo (Zosteraceae; Smith \& al., 2018).

\section{The circumscription of Hyalosepalum}

Owing to the fact that the generic name Desmonema (Menispermaceae; Miers, 1867) was first used in Euphorbiaceae by Rafinesque (1833), Troupin (1949) provided a newgeneric name, Hyalosepalum, to accommodate eight African species. However, later, Troupin (1962) deemed that whether stamens were free or not was not enough to separate Hyalosepalum and Tinospora, and therefore reduced the former to the latter. Earlier phylogenetic analyses have indicated that T. caffra $(=\mathrm{H}$. caffrum, the type of Hyalosepalum $)$ has a distant relationship with Tinospora (Ahmad \& al., 2009; Hoot \& al., 2009; Jacques \& al., 2011; Wefferling \& al., 2013; Ortiz \& al., 2016; Wang \& al., 2017). Thus, Wang \& al. (2017) resurrected Hyalosepalum; however, the circumscription of the resurrected genus has been challenging since only two out of the eight species of Hyalosepalum were sampled. Hyalosepalum uviforme (Baill.) Troupin (= Tinospora uviforme) has been 
confirmed to be a member of Chasmanthera, i.e., C. uviforme Baill. (Ortiz \& al., 2016; this study). Here, we included T. oblongifolia $(=\mathrm{H}$. oblongifolium (Engl.) Troupin) and T. tenera Miers $(=\mathrm{H}$. tenerum (Miers) Troupin) in molecular phylogenetic analyses for the first time. Tinospora oblongifolia groups with $\mathrm{H}$. caffrum with moderate support $(\mathrm{BS}=72 \%, \mathrm{PP}=0.96$; Fig. 1$)$. The two species share three stamens with connate filaments, whereas Tinospora species have six free stamens (Diels, 1910; Troupin, 1962). Conversely, H. tenerum was embedded within Tinospora with strong support (Fig. 1). In agreement with this relationship is the shared presence of six stamens (Diels, 1910; Troupin, 1962). The filaments of H. tenerum are only connate at the base, whereas the filaments of other Hyalosepalum are completely connate.

\section{Evolution of morphological characters}

Sepal and stamen characters, including number of sepal whorls, number of stamens, stamen connation, dehiscence type of anthers, and pollen aperture type, have traditionally been used for generic recognition within Burasaieae, especially for the delimitation of Tinospora. These characters are traced on the phylogeny of the combined cpDNA and ITS data (Fig. 3). Likelihood inference indicates evolutionary patterns of morphological characters (Fig. 4). The clade containing Dioscoreophyllum and the broad Chasmanthera has two whorls of sepals, a feature that is also found in Paratinospora, Disciphania and Parabaena. Most genera of Burasaieae have six stamens. In the broad Chasmanthera, the state "three stamens" originated once, and reversals to "six stamens" occurred in Leptoterantha and Odontocarya truncata Standl., respectively. Free stamens are the plesiomorphic state of Burasaieae, and connate stamens have evolved four times independently. In Rhigiocarya, Kolobopetalum and Odontocarya truncata, the outer three stamens are free and the inner three are connate. Our phylogenetic hypothesis suggests that the dehiscence of anthers and pollen aperture types are extremely complex in the broad Chasmanthera.

The number of stamens, the presence/absence of stamen connation, dehiscence type of anthers, and pollen aperture types are homoplastic in the broad Chasmanthera, but each genus of the broad Chasmanthera has at least one unique combination of these four morphological characters except for Tinospora and Sarcolophium (Fig. 3). However, Sarcolophium is distinguished from Tinospora by having an endocarp with erect processes (vs. verruca or tubercule; Kessler, 1993). Our phylogenetic analyses indicate that there are 11 genera in the broad Chasmanthera (Fig. 1, suppl. Fig. S1). If the broad generic concept of Baillon (1872) is accepted, it will be extremely disruptive for nomenclature because numerous new nomenclatural combinations will be required, especially since both Tinospora and Odontocarya contain more than 30 species (Ortiz \& al., 2016). Considering phylogenetic and morphological evidence and the nomenclatural option, here we conclude that segregation of these 11 genera is strongly preferable, in agreement with earlier authors (e.g., Diels, 1910; Troupin, 1962; Kessler, 1993; Ortiz \& al., 2016; Wang \& al., 2017).

\section{Biogeography of Tinospora}

Our time estimates for Burasaieae are consistent with the results of previous studies (Wang \& al., 2012, 2017). This was anticipant because the same calibration fossils were used. Our results indicate that Tinospora originated from Africa in the Oligocene (28.57 Ma, 95\% HPD: 22.67-34.76; node 2 in Fig. 6), and its most recent common ancestor likely had spread into Asia in the Early Miocene (21.54 Ma, 95\% HPD: 15.63-27.62; node 3). There are four main competing hypotheses to explain floristic exchanges between the African and Asian tropics: Gondwanan vicariance or Indian raft, boreotropical migration, Miocene geodispersal, and long-distance dispersal (reviewed in Thomas \& al., 2015). Our estimated age for the dispersal from Africa to Asia is obviously younger than the timing of collision of India and continental Asia, ca. $50 \mathrm{Ma}$ (Van Hinsbergen \& al., 2012) or $35 \mathrm{Ma}$ (Ali \& Aitchison, 2008), and also younger than the timing of disruption of the boreotropical forests, ca. $34 \mathrm{Ma}$ (Collinson, 1992; Wolfe, 1992; Morley, 2007). Thus, the Indian raft and boreotropical migration hypotheses were rejected, while the Miocene geodispersal hypothesis is temporally congruent with our inferences. During the Early to Middle Miocene, global climate was warming (Zachos \& al., 2001). Moreover, due to the collision of the Afro-Arabian plate with the Iranian and Anatolian plates, land connections between Africa and Southwest Asia developed during this period (Rögl, 1998; Popov \& al., 2004). Evidence from plant and vertebrate macrofossils and palynological data indicate that there were tropical forests in Arabia from the Early to Middle Miocene (Mandaville, 1984; Kürschner, 1998; Otero \& Gayet, 2001; Ataabadi, 2010; Pound \& al., 2012). Tinospora species primarily inhabit tropical rainforests, monsoon forests, and open woodlands (Troupin, 1962; Forman, 1986). Thus, the Arabian corridor during the Early to Middle Miocene may have facilitated the range expansion of Tinospora. Other tropical lineages, such as Annonaceae (Zhou \& al., 2012; Thomas \& al., 2015), Isodon (Schrad. ex Benth.) Spach (Lamiaceae; Yu \& al., 2014), and Searsia F.A.Barkley (Anacardiaceae; Yang $\&$ al., 2016), have also migrated through Arabia during this period.

Our analyses indicate that Tinospora was widely distributed in Africa and Asia until a vicariance event occurred in the Middle Miocene (17.53 Ma, 12.02-23.39 Ma; node 4), which resulted in the divergence of the African T. 
tenera and its Asian allies. After the late Middle Miocene, climate deterioration occurred (Zachos \& al., 2001), which may have hampered the exchange of megathermal plants between Africa and Asia through Arabia.

The African T. bakis originated from Asia in the Late Miocene (9.71 Ma, 5.84- 14.61 Ma) with the extinction of its Asian ancestor (node 6 in Fig. 6). This age is younger than the disruption of the aforementioned Arabian Miocene corridor. Thus, transoceanic long-distance dispersal may be the most likely explanation for this colonization event. The fruits of Tinospora are brightly colored and fleshy drupes (Forman, 1986), which may be favored by birds. Transoceanic longdistance dispersal has been hypothesized to explain the Asian- African disjunction for other plant groups, such as Adansonia L. (Malvaceae; Baum\&al., 1998), Osbeckia L. (Melastomataceae; Renner \& Meyer, 2001), and Loranthaceae (Liu \& al., 2018).

The clade including the Australian T. smilacina and T. esiangkara originated from Asia in early Late Miocene (11.16 Ma, 7.15- 15.92 Ma; node 5), obviously later than the convergence between Asia and New Guinea/Australian plates, ca. 25 Ma (Morley, 1998; Hall, 2002, 2009). This convergence led to the formation of the Wallacean transition zone between the Sunda and the Sahul shelves, and some taxa have dispersed from one side to the other (Richardson \& al., 2012). The winteraceous fossil leaves collected from the Middle Miocene in Central Yunnan support the exchange of megathermal plants between Gondwana and Asia after the convergence (Liang \& al., 2018). The "west-to-east" migration pattern in Tinospora is also found in some other plant taxa, such as Pseuduvaria Miq. (Annonaceae; Su \& Saunders, 2009), Alocasia (Schott) G.Don (Araceae; Nauheimer $\&$ al., 2012), and Begonia L. (Begoniaceae; Thomas \& al., 2012).

\section{AUTHOR CONTRIBUTIONS}

WW designed the research. LL performed the lab work and analyzed data. RDCO, FJ, ZDC and WW collected the materials. LL and WWinterpreted the results and wrote the paper. All authors contributed with further discussion and writing of the manuscript. - RDCO, https://orcid.org/0000-0002-4673-4347; FJ, https://orcid.org/0000-0002-7729-1067; WW, https://orcid.org/0000-0001-6901-6375

\section{ACKNOWLEDGMENTS}

We sincerely thank Dr. Peter F. Stevens for kindly reading an earlier draft. The curators of MO and P are acknowledged for sharing plant materials. This research was partially funded by the Strategic Priority Research Program of the Chinese Academy of Sciences (XDB31030000) and the National Natural Science Foundation of China (Grant nos. 31470315, 31770231 and 31770233).

\section{LITERATURE CITED}

Ahmad, S.M., Hoot, S.B., Qazi, P.H.\&Verma, V. 2009. Phylogenetic patterns and genetic diversity of Indian Tinospora species based on chloroplast sequence data and cytochrome P450 polymorphisms. Pl. Syst. Evol. 281: 87-96. https://doi.org/10.1007/s00606-009-0189-1

Ali, J.R. \& Aitchison, J.C. 2008. Gondwana to Asia: Plate tectonics, paleogeography and the biological connectivity of the Indian sub-continent from the Middle Jurassic through latest Eocene (166-35 Ma). Earth-Sci. Rev. 88: 145-166. https://doi.org/10.1016/j.earscirev.2008.01.007

Ataabadi, M.M. 2010. The Miocene of western Asia: Fossil mammals at the cross-roads of faunal provinces and climate regimes. Helsinki: University of Helsinki.

Bailey, F.M. 1899. The Queensland flora, part 1. Brisbane: printed by H.J. Diddams. https://doi.org/10.5962/bhl.title.54432

Baillon, H. 1872. Histoire des plantes, vol. 3. Paris: Librairie Hachette et Cie. https://doi.org/10.5962/bhl.title.40796

Bänziger, H. 1982. Fruit-piercing moths (Lep., Noctuidae) in Thailand: A general survey and some new perspectives. Mitt. Schweiz. Entomol. Ges. 55: 213-240.

Barneby, R.C. 1970. Revision of Neotropical Menispermaceae tribe Tinosporeae. Mem. New York Bot. Gard. 20: 81-158.

Barneby, R.C. 1972. New and notable Menispermaceae tribe Tinosporeae. Mem. New York Bot. Gard. 22: 137151.

Bartish, I.V., Antonelli, A., Richardson, J.E. \& Swenson, U. 2011. Vicariance or long-distance dispersal: Historical biogeography of the pantropical subfamily Chrysophylloideae (Sapotaceae). J. Biogeogr. 38: 177190. https://doi.org/10.1111/j.1365-2699.2010.02389.x

Baum, D.A., Small, R.L. \& Wendel, J.F. 1998. Biogeography and floral evolution of baobabs (Adansonia, Bombacaceae) as inferred from multiple data sets. Syst. Biol. 47: 181-207. https://doi.org/10.1080/106351598260879

Blattner, F.R. 1999. Direct amplification of the entire ITS region from poorly preserved plant material using recombinant PCR. Biotechniques 29: 1180-1186. https://doi.org/10.2144/99276st04 
Buerki, S., Forest, F., Alvarez, N., Jaa, N., Arrigo, N.\&Sanmartín, I. 2011. An evaluation of new parsimonybased versus parametric inferencemethods in biogeography: A case study using the globally distributed plant family Sapindaceae. J. Biogeogr. 38: 531-550. https://doi.org/10.1111/j.1365-2699.2010.02432.x

Chandler, M.E.J. 1964. The Lower Tertiary Floras of southern England IV: A summary and survey of findings in the light of recent botanical observations. London: British Museum (Natural History).

Collinson, M. 1992. Vegetational and floristic changes around the Eocene/Oligocene boundary in western and central Europe. Pp. 437-450 in: Prothero, D.R. \& Berggren, W.A. (eds.), Eocene-Oligocene climatic and biotic evolution. Princeton, NJ: Princeton University Press.

Diels, L. 1910. Menispermaceae. In: Engler, A. (ed.), Das Pflanzenreich, IV, 94 (Heft 46). Leipzig: Engelmann. Drummond, A.J., Suchard, M.A., Xie, D. \& Rambaut, A. 2012. Bayesian phylogenetics with BEAUti and the BEAST 1.7. Molec. Biol. Evol. 29: 1969-1973. https://doi.org/10.1093/molbev/mss075

Fairon-Demaret, M. \& Smith, T. 2002. Fruits and seeds from the Tienen Formation at Dormaal, PaleoceneEocene transition in eastern Belgium. Rev. Palaeobot. Palynol. 122: 47-62. https://doi.org/10.1016/S00346667(02)00103-3

Forman, L.L. 1981. A revision of Tinospora (Menispermaceae) in Asia to Australia and the Pacific. Kew Bull. 36: 375-421. https://doi.org/10.2307/4113613

Forman, L.L. 1986. Menispermaceae. Pp. 157-253 in: Van Steenis, C.G.G.J. \& De Wilde, W.J.J.O. (eds.), Flora Malesiana, vol. 10(2). Dordrecht: Kluwer.

Forman, L.L. 2007. Menispermaceae. Pp. 362-386 in: Flora of Australia, vol. 2. Melbourne: ABRS, CSIRO.

Givnish, T.J. \& Renner, S.S. 2004. Tropical intercontinental disjunctions: Gondwana breakup, immigration from the boreotropics, and transoceanic dispersal. Int. J. P1. Sci. 165: S1-S6. https://doi.org/10.1086/424022

Hall, R. 2002. Cenozoic geological and plate tectonic evolution of Southeast Asia and the Southwest Pacific: Computer-based reconstructions, model and animations. J. Asian Earth Sci. 20: 353-434. https://doi.org/10.1016/s1367-9120(01)00069-4

Hall, R. 2009. Southeast Asia's changing palaeogeography. Blumea 54: 148-161. https://doi.org/10.3767/000651909x475941

Hall, T.A. 1999. BioEdit: A user-friendly biological sequence alignment editor and analysis program for Windows 95/98/NT. Nucl. Acids Symp. Ser. 41: 95-98. https://doi.org/10.1021/bk-1999-0734.ch008

Hoot, S.B., Zautke, H., Harris, D.J., Crane, P.R.\&Neves, S.S. 2009. Phylogenetic patterns in Menispermaceae based on multiple chloroplast sequence data. Syst. Bot. 34: 44-56. https://doi.org/10.1600/036364409787602339 Jacques, F.M.B., Wang, W., Ortiz, R.D.C., Zhou, Z.K., Li, H.L. \& Chen, Z.D. 2011. Integrating fossils in a molecular-based phylogeny and testing them as calibration points for divergence time estimates in Menispermaceae. J. Syst. Evol. 49: 25-49. https://doi.org/10.1111/j.1759-6831.2010.00105.x

Kearse, M., Moir, R., Wilson, A., Stones-Havas, S., Cheung, M., Sturrock, S., Buxton, S., Cooper, A., Markowitz, S., Duran, C., Thierer, T., Ashton, B., Mentjies, P. \& Drummond, A. 2012. Geneious basic: An integrated and extendable desktop software platform for the organization and analysis of sequence data. Bioinformatics 28: 1647-1649. https://doi.org/10.1093/bioinformatics/bts199

Kessler, P.J.A. 1993. Menispermaceae. Pp. 402-418 in: Kubitzki, K., Rohwer, J.G. \& Bittrich, V. (eds.), The families and genera of vascular plants, vol. 2. Berlin: Springer.

Knapp, M., Stockier, K., Havell, D., Delsuc, F., Sebastiani, F. \& Lockhart, P.J. 2005. Relaxed molecular clock provides evidence for long-distance dispersal of Nothofagus (southern beech). PLoS Biol. 3: e14. https://doi.org/10.1371/journal.pbio.0030014

Kürschner, H. 1998. Biogeography and introduction to vegetation. Pp. 63-98 in: Ghazanfar, S.A. \& Fisher, M. (eds.), Vegetation of the Arabian peninsula. Berlin: Springer.

Lewis, P.O. 2001. A likelihood approach to estimating phylogeny from discrete morphological character. Syst. Biol. 50: 913-925. https:// doi.org/10.1080/106351501753462876

Lian, L., Xiang, K.L., Ortiz, R.D.C. \& Wang, W. 2019. A multi-locus phylogeny for the Neotropical Anomospermeae (Menispermaceae): Implications for taxonomy and biogeography. Molec. Phylogen. Evol. 139: 44-52. https://doi.org/10.1016/j.ympev.2019.04.006

Liang, X.Q., Lu, P., Zhang, J.W., Su, T. \& Zhou, Z.K. 2018. First fossils of Zygogynum, from the Middle Miocene of central Yunnan, southwest China, and their palaeobiogeographic significance. Palaeoworld 27: 399409. https://doi.org/10.1016/j.palwor.2018.05.003

Liu, B., Le, C.T., Barrett, R.L., Nickrent, D.L., Chen, Z., Lu, L. \& Vidal-Russell, R. 2018. Historical biogeography of Loranthaceae (Santalales): Diversification agrees with emergence of tropical forests and radiation of songbirds. Molec. Phylogen. Evol. 124: 199-212. https://doi.org/10.1016/j.ympev.2018.03.010

Luo, H.S. 1996. Menispermaceae. Pp. 1-81 in: Flora Republicae Popularis Sinicae, vol. 30 (1). Beijing: Science Press.

Mabberley, D.J. 2017. Mabberley's plant-book: A portable dictionary of plants, their classifications, and uses, 4th ed. Cambridge, U.K.: Cambridge University Press.

Maddison, W. \& Maddison, D.R. 2011. Mesquite, version 2.75. http://mesquiteproject.org 
Manchester, S.R. 1994. Fruits and seeds of Middle Eocene Nut Beds Flora, Clarno formation Oregon. Palaeontogr. Amer. 58: 1-205.

Mandaville, J.P. 1984. Studies in the flora of Arabia XI: Some historical and geographical aspects of a principal floristic frontier. Notes Roy. Bot. Gard. Edinburgh 42: 1-15.

Matzke, N.J. 2013. Probabilistic historical biogeography: New models for founder event speciation, imperfect detection, and fossils allow improved accuracy and model-testing. Frontiers Biogeogr. 5: 242-248. https://doi.org/10.21425/f5fbg19694

McLoughlin, S. 2001. The breakup history of Gondwana and its impact on pre-Cenozoic floristic provincialism. Austral. J. Bot. 49: 271-300. https://doi.org/10.1071/bt00023

Miers, J. 1867. On the Menispermaceae. Ann. Mag. Nat. Hist., ser. 3, 20: 260-266.

Morley, R.J. 1998. Palynological evidence for Tertiary plant dispersals in the Southeast Asian region in relation to plate tectonics and climate. Pp. 211-234 in: Hall, R. \& Holloway, J. (eds.), Biogeography and geological evolution of SE Asia. Leiden: Backhuys.

Morley, R.J. 2003. Interplate dispersal paths for megathermal angiosperms. Perspect. Pl. Ecol. Evol. Syst. 6: 520. https://doi.org/10.1078/1433-8319-00039

Morley, R.J. 2007. Cretaceous and Tertiary climate change and the past distribution of megathermal rainforests. Pp. 1-31 in: Flenley, J.R. \& Bush, M.B. (eds.), Tropical rainforest responses to climatic changes. Berlin: Springer.

Mueller, F. 1877 [“1876-1877”]. Menispermaceae. Pp. 93-94 in: Fragmenta phytographiae Australiae, vol. 10. Melbourne: Auctoritate Guberni Coloniae Victoriae, ex officina Joannis Ferres. https://doi.org/10.5962/bhl.title.287

Nauheimer, L., Metzler, D. \& Renner, S. 2012. Global history of the ancient monocot family Araceae inferred with models accounting for past continental positions and previous ranges based on fossils. New Phytol. 195: 938-950. https://doi.org/10.1111/j.1469-8137.2012.04220.x

Ortiz, R.D.C., Kellogg, E.A. \& Van der Werff, H. 2007. Molecular phylogeny of the moonseed family (Menispermaceae): Implications for morphological diversification. Amer. J. Bot. 94: 1425-1438. https://doi.org/10.3732/ajb.94.8.1425

Ortiz, R.D.C., Wang,W., Jacques, F.M.B. \& Chen, Z.D. 2016. Phylogeny and a revised tribal classification of Menispermaceae based on molecular and morphological data. Taxon 65: 1288-

1312. https://doi.org/10.12705/656.5

Otero, O. \& Gayet, M. 2001. Palaeoichthyofaunas from the lower Oligocene and Miocene of the Arabian plate: Palaeoecological and palaeobiogeographical implications. Palaeogeogr. Palaeoclimatol. Palaeocl. 165: 141-169. https://doi.org/10.1016/s0031-0182(00)00158-9

Parham, J.F., Donoghue, P.C.J., Bell, C.J., Calway, T.D., Head, J.J., Holroyd, P.A., Inoue, J.G., Irmis, R.B., Joyce, W.G., Ksepka, D.T., Patané, J.S.L., Smith, N.D., Tarver, J.E., van Tuinen, M., Yang, Z., Angielczyk, K.D., Greenwood, J.M., Hipsley, C.A., Jacobs, L., Makovicky, P.J., Müller, J., Smith, K.T., Theodor, J.M., Warnock, R.C.M. \& Benton, M.J. 2012. Best practices for justifying fossil calibrations. Syst. Biol. 61: 346-359. https://doi.org/10.1093/sysbio/syr107

Popov, S., Rögl, F., Rozanov, A., Steininger, F.F., Shcherba, I. \& Kovac, M. 2004. Lithological-Paleogeographic maps of Paratethys: 10 maps Late Eocene to Pliocene. Courier Forschungsinst. Senckenberg 250: 1-46.

Posada, D. 2008. jModelTest: Phylogenetic model averaging. Molec. Biol. Evol. 25: 1253-1256. https://doi.org/10.1093/molbev/msn083

Pound, M.J., Haywood, A.M., Salzmann, U. \& Riding, J.B. 2012. Global vegetation dynamics and latitudinal temperature gradients during the Mid to Late Miocene (15.97-5.33 Ma). Earth-Sci. Rev. 112: 1-22. https://doi.org/10.1016/j.earscirev.2012.02.005

Rafinesque, C.S. 1833. Herbarium Rafinesquianum: Herbals, or botanical collections of C.S. Rafinesque, I. Atlantic J. 1: 177.

Rambaut, A., Suchard, M.A., Xie, D. \& Drummond, A.J. 2014. Tracer, version 1.6. http://beast.bio.ed.ac.uk/Tracer/

Ree, R.H. \& Sanmartín, I. 2018. Conceptual and statistical problems with the DEC + J model of founder-event speciation and its comparison with DEC via model selection. J. Biogeogr. 45: 741-749. https://doi.org/10.1111/jbi.13173

Ree, R.H. \& Smith, S.A. 2008. Maximum likelihood inference of geographic range evolution by dispersal, local extinction, and cladogenesis. Syst. Biol. 57: 4-14. https://doi.org/10.1080/10635150701883881

Renner, S.S. \& Meyer, K. 2001. Melastomataceae come full circle: Biogeographic reconstruction and molecular clock dating. Evolution 55: 1315-1324. https://doi.org/10.1554/0014-3820(2001)055

Richardson, J.E. Costion, C.\& Muellner, A. 2012. The Malesian floristic interchange: Plant migration patterns across Wallace's Line. Pp. 138-163 in: Gower, D., Johnson, K., Rüber, L. \& Williams, S. (eds.), Biotic evolution and environmental change in Southeast Asia. Cambridge, U.K.: Cambridge University Press. 
Rögl, F. 1998. Palaeogeographic considerations for Mediterranean and Paratethys seaways (Oligocene to Miocene). Ann. Naturhist. Mus. Wien, A 99: 279-310.

Ronquist, F., Teslenko, M., Van der Mark, P., Ayres, D.L., Darling, A., Höhna, S., Larget, B., Liu, L., Suchard, M.A. \& Huelsenbeck, J.P. 2012. MrBayes 3.2: Efficient Bayesian phylogenetic inference and model choice across a large model space. Syst. Biol. 61: 539-542. https://doi.org/10.1093/sysbio/sys029

Sáez, A., Caberra, L., Jensen, A. \& Chong, G. 1999. Late Neogene lacustrine record and palaeogeography in the Quillagua-Llamara Basin, central Andean fore-arc (northern Chile). Palaeogeogr. Palaeoclimatol. Palaeoecol. 151: 5-37.

Smith, T.M., York, P.H., Broitman, B.R., Thiel, M., Hays, G.C., Van Sebille, E., Putman, N.F., Macreadie, P.I. \& Sherman, C.D.H. 2018. Rare long-distance dispersal of a marine angiosperm across the Pacific Ocean. Global Ecol. Biogeogr. 27: 487-496. https://doi.org/10.1111/geb.12713

Stamatakis, A. 2006. RAxML-VI-HPC: Maximum likelihood-based phylogenetic analyses with thousands of taxa and mixed models. Bioinformatics 22: 2688-2690. https://doi.org/10.1093/bioinformatics/btl446

Su, Y.C.F. \& Saunders, R.M.K. 2009. Evolutionary divergence times in the Annonaceae: Evidence of a late Miocene origin of Pseuduvaria in Sundaland with subsequent diversification in New Guinea. B. M. C. Evol. Biol. 9: 153. https://doi.org/10.1186/1471-2148-9-153

Thanikaimoni, G., Roland, F., Ferguson, I.K., Cerceau, M.T. \& Derouet, L. 1984. Menispermacées: Palynologie et systématique. Trav. Sect. Sci. Techn. Inst. Franç. Pondichéry 18: 1-134.

Thomas, D.C., Surveswaran, S., Xue, B., Sankowsky, G., Mols, J.B., Keßler, P. \& Saunders, R.M.K. 2012. Molecular phylogenetics and historical biogeography of the Meiogyne-Fitzalania clade (Annonaceae): Generic paraphyly and late Miocene-Pliocene diversification in Australasia and the Pacific. Taxon 61: 559-575. https://doi.org/10.1002/tax.613006

Thomas, D.C., Chatrou, L.W., Stull, G.W., Johnson, D.M., Harris, D.J., Thongpairoj, U.S. \& Saunders, R.M.K. 2015.

The historical origins of palaeotropical intercontinental disjunctions in the pantropical flowering plant family Annonaceae. Perspect. Pl. Ecol. Evol. Syst. 17: 1-16. https://doi.org/10.1016/j.ppees.2014.11.001

Thorne, R.F. 1972. Major disjunctions in the geographic ranges of seed plants. Quart. Rev. Biol. 47: 365-411.

Troupin, G. 1949. Contribution à l'étude des Menispermacees africaines-I. Bull. Jard. Bot. État Bruxelles 19: 409-435.

Troupin, G. 1962. Monographie des Menispermaceae Africaines. Mém. Acad. Roy. Sci. Outre-Mer, Cl. Sci. Nat. Méd. 13: 1-313.

Van Hinsbergen, D.J., Lippert, P.C., Dupont-Nivet, G., McQuarrie, N., Doubrovine, P.V., Spakman, W. \& Torsvik, T.H. 2012. Greater India Basin hypothesis and a two-stage Cenozoic collision between India and Asia. Proc. Natl. Acad. Sci. U.S.A. 109: 7659-7664. https://doi.org/10.1073/pnas.1117262109

Vicente, N., Kergoat, G.J., Dong, J., Yotoko, K., Legendre, F., Nattier, R. \& Robillard, T. 2017. In and out of the Neotropics: Historical biogeography of Eneopterinae crickets. J. Biogeogr. 44: 1254-1265. https://doi.org/10.1111/jbi.13026

Wang, W., Ortiz, R.D.C., Jacques, F.M.B., Xiang, X.G., Li, H.L., Lin, L., Li, R.Q., Liu, Y., Soltis, P.S., Soltis, D.E. \& Chen, Z.D. 2012. Menispermaceae and the diversification of tropical rainforests near the CretaceousPaleogene boundary. New Phytol. 195: 470-478. https://doi.org/10.1111/j.1469-8137.2012.04158.x

Wang, W., Li, H.L. \& Chen, Z.D. 2014. The analysis of chloroplast and nuclear DNA data in plant phylogenetics-Evaluation and improvement. Sci. China, C 57: 280-286. https://doi.org/10.1007/s11427-0144620-7

Wang, W., Ortiz, R.D.C., Jacques, F.M.B., Chung, S.W., Liu, Y., Xiang, X.G. \& Chen, Z.D. 2017. New insights into the phylogeny of Burasaieae (Menispermaceae) with the recognition of a new genus and emphasis on the southern Taiwanese and mainland Chinese disjunction. Molec. Phylogen. Evol. 109: 11-20. https:// doi.org/10.1016/j.ympev.2016.12.038

Wefferling, K.M.\& Hoot, S.B. 2018. Dated phylogeography of western NorthAmerican subalpine marshmarigolds (Caltha spp., Ranunculaceae): Miocene-Pliocene divergence of hexaploids, multiple origins of allododecaploids during the Pleistocene, and repeated recolonization of Last Glacial Maximum glaciated regions. J. Biogeogr. 45: 1077-1089. https://doi.org/10.1111/jbi.13204

Wefferling, K.M., Hoot, S.B.\&Neves, S.S. 2013. Phylogeny and fruit evolution in Menispermaceae. Amer. J. Bot. 100: 883-905. https://doi.org/10.3732/ajb.1200556

Wolfe, J.A. 1992. Climatic, floristic, and vegetational changes near the Eocene/Oligocene boundary in North America. Pp. 421-436 in: Prothero, D.R. \& Berggren, W.A. (eds.), Eocene-Oligocene biotic and climatic evolution. Princeton, NJ: Princeton University Press.

Yang, Y.Y., Meng, Y., Wen, J., Sun, H. \& Nie, Z.L. 2016. Phylogenetic analyses of Searsia (Anacardiaceae) from eastern Asia and its biogeographic disjunction with its African relatives. S. African J. Bot. 106: 129-136. https://doi.org/10.1016/j.sajb.2016.05.021 
Yokoyama, J., Suzuki, M., Iwatsuki, K. \& Hasebe, M. 2000. Molecular phylogeny of Coriaria, with special emphasis on the disjunct distribution. Molec. Phylogen. Evol. 14: 11-19. https://doi.org/10.1006/mpev.1999.0672

Yu, X.Q., Maki, M., Drew, B.T., Paton, A.J., Li, H.W., Zhao, J.L., Conran, J.G. \& Li, J. 2014. Phylogeny and historical biogeography of Isodon (Lamiaceae): Rapid radiation in south-west China and Miocene overland dispersal into Africa. Molec. Phylogen. Evol. 77: 183-194. https://doi.org/10.1016/j.ympev.2014.04.017

Zachos, J., Pagani, M., Sloan, L., Thomas, E. \& Billups,K. 2001. Trends, rhythms, and aberrations in global climate 65 Ma to present. Science 292: 686-693. https://doi.org/10.1126/science.1059412

Zhou, L.L., Su, Y.C.F., Thomas, D.C.\& Saunders, R.M.K. 2012. 'Out of- Africa' dispersal of tropical floras during the Miocene climatic optimum: Evidence from Uvaria (Annonaceae). J. Biogeogr. 39: $322-335$. https://doi.org/10.1111/j.1365-2699.2011.02598.x

Appendix 1. Taxa, voucher identification and GenBank accession numbers for molecular analyses of the tribe Burasaieae.

Species, locality, voucher, and GenBank accession: ITS, trnL-F, matK, ndhF, rbcL, and atpB. An asterisk (*) indicates newly generated sequences in this study, a dash (-) denotes missing data.

INGROUPS: Aspidocarya uvifera Hook.f. \& Thomson, China, Hong YP 99190 (PE), KY365639, EF143884, EF143853, JN051701, FJ626593, HQ260821. Borismene japurensis (Mart.) Barneby, cult. Belgium, D. Aplin S4033 (BR), KY365640, JN051746, JN051812, JN051702, JN051675, JN051871. Burasaia madagascariensis Thou., Madagascar, Rabenantoandro \& al. 1262 (MO), KY365641, JN051747, JN051813, EF624272, HQ260767, HQ260823. Calycocarpum lyonii Nutt. ex A.Gray, U.S.A., Ortiz \& al. 335 (MO), KY365642, JN051748, JN051814, EF624273, HQ260768, HQ260824. Chasmanthera uviformis Baill., Madagascar, P. Antilahimena 7571 (MO), MK670923*, KX384146, KX384083, KX384106, MK670938*, MK670944*. Chasmanthera welwitschii Troupin, cult. Belgium, D. Aplin S4040 (BR), KY365643, JN051751, JN051817, EF624277, EU526985, HQ260827. Dialytheca gossweileri Exell \& Mendonça, Gabon, F.J. Breteler 371 (MO), MK670924*, KX384130, KX384067, KX384098, MK670939*, -. Dioscoreophyllum cumminsii (Stapf) Diels, cult. Belgium, D. Aplin S4049 (BR), KY365644, JN051759, JN051825, EF624294, EU526988, EU526972. Disciphania killipii Diels, Peru, Ortiz \& Zárate 310 (AMAZ, MO), KY365645, JN051760, JN051826, EF624295, HQ260779, HQ260835. Fibraurea recisa Pierre, China, Jin XH PT-2516 (PE), MK670925*, MK670931*, MK670934*, MK670936*, MK670940*, MK670945*. Fibraurea tinctoria Lour., cult. West Java, F. Jacques 04 (P), KY365646, JN051762, JN051828, EF624298, HQ260781, EU526970. Hyalosepalum caffrum (Miers) Troupin, Tanzania, Sitoni \& al. 1257 (MO), -, -, KX384082, -, L37923, L37933. Jateorhiza macrantha (Hook.f.) Exell \& Mendonça, Cameroon, Kenfack \& Zapfack 2039 (MO), KY365647, JN051766, JN051832, EF624305, HQ260785, HQ260840. Kolobopetalum leonense Hutchinson \& Dalziel, Ghana, Schmidt \& al. 3435 (MO), KY365648, JN051767, JN051833, EF624306, HQ260786, HQ260841. Leptoterantha mayumbensis (Exell) Troupin, Congo, Ewango 3005 (MO), KY365649, JN051769, JN051835, EF624308, HQ260788, HQ260788. Odontocarya tripetala Diels, Peru, Ruiz 5601 (MO), KY365650, JN051772, JN051837, EF624316, HQ260789, HQ260845. Odontocarya truncata Standl., Costa Rica, Hammel \& Perez 22567 (MO), KY365651, JN051773, JN051838, EF624317, HQ260790, HQ260846. Orthogynium sp., Madagascar, Birkinshaw \& Rabenantoandro 549 (MO), KY365652, JN051774, JN051839, EF624318, JN051684, JN051880. Parabaena sagittata Miers ex Hook.f. \& Thomson, China, Hong YP H346 (PE), KY365653, EF143885, EF143854, JN051714, FJ626597, HQ260849. Paratinospora dentata (Diels) Wei Wang, China, Chen \& al. 20110517-1 (PE), KY365662, KY365726, KY365679, KY365695, KY365711, KY365627. Paratinospora sagittata (Oliv.) Wei Wang, China, Anonymous 1055 (PE), KY365665, KY365729, KY365682, KY365697, KY365713, KY365629. Penianthus longifolius Miers, Cameroon, Sweeney \& al. 1436 (MO), KY365654, JN051779, JN051844, EF624323, HQ260794, HQ260850. Penianthus patulinervis Hutch. \& Dalziel, Ivory Coast, M.T. Thijssen 378 (MO), MK670926*, KX384139, KX384076, -, FJ026500, FJ026440. Rhigiocarya racemifera Miers, Cameroon, Kenfack 1655 (MO), KY365655, JN051784, JN051849, EF624328, HQ260797, HQ260853. Sarcolophium suberosum Troupin, Gabon, F.J. Breteler 12819 (MO), MK670927*, KX384141, -, KX384104, MK670941*, -. Sphenocentrum jollyanum Pierre, Nigeria, Daramota 30 (MO), KY365656, JN051787, JN051852, EF624334, JN051687, JN051885. Syntriandrium preussii Engl., Cameroon, Fernandez Casas MK 8407 (PE), KY365657, JN051794, JN051859, JN051729, HQ260804, HQ260860. Tinomiscium petiolare Hook.f. \& Thomson, China, Hong YP H142 (PE), KY365658, EF143888, EF143857, JN051732, EF173675, HQ260863. Tinospora baenzigeri Forman, Thailand, Wang HC 108 (PE), KY365659, KY365723, KY365676, KY365692, KY365708, KY365624. Tinospora bakis (A.Rich.) Miers, cult. West Java, F. Jacques s.n. (P), KY365660, KY365724, KY365677, KY365693, KY365709, KY365625. Tinospora cordifolia (Willd.) Miers ex Hook.f. \& Thomson, India, M. Immanuel Sagayaraj 56237 (RHJ) AY660534, KJ641530, JX193231, -, 
DQ353864, DQ353860. Tinospora crispa (L.) Hook.f. \& Thomson, cult. Singapore, Chen ZD s.n. (PE), KY365661, KY365725, KY365678, KY365694, KY365710, KY365626. Tinospora esiangkara (F.M. Bailey) Forman, Australia, Gray 8927 (MO), KY365663, KY365727, KY365680, EF624310, HQ260807, HQ260864. Tinospora glabra (Burm.f.) Merr., cult. West Java, F. Jacques 03 (P), KY365664, KY365728, KY365681, KY365696, KY365712, KY365628. Tinospora macrocarpa Diels, Malaysia, AS213, -, KU853223, KU853097, -, KU853168, -. Tinospora malabarica (Lam.) Hook.f. \& Thomson, India, Ahmad \& al. (2009), AY626991,-, -, -, DQ414465, DQ353859. Tinospora neocaledonica Forman, New Caledonia, H.S. McKee 41473 (P), MK670928*, -, -, -, -, - . Tinospora oblongifolia (Engl.) Troupin, Kenya, J.B. Gillett \& S.P. Kibuwa 19891 (P), MK670929*, MK670932*, -, -, MK670942*, -. Tinospora siamensis Forman, Thailand, Wang HC 111 (PE), KY365674, KY365738, KY365691, KY365706, KY365722, KY365638. Tinospora sinensis (Lour.) Merr., Thailand, Wang HC 109 (PE), AY017386, EF143886, EF143855, KX384105, FJ626602, KY365637. Tinospora smilacina Benth., Australia, Gray 8798 (MO), KY365675, JN051800, JN051865, EF624343, HQ260809, HQ260865. Tinospora sp., Indonesia, Chen ZD\&Lu LM227 (PE), MK670930*, MK670933*, MK670935*, MK670937*, MK670943*, MK670946*. Tinospora tenera Miers, South Africa, OM1369, -, -, JX517669, -, JX573051, - . Tinospora tinosporoides (F.Muell.) Forman, Australia, 129307961, -, -, KM894867, -, KM896038, - .

OUTGROUPS: Anamirta cocculus (L.) Wight \& Arn., Thailand, Wang HC 103 (HIB), FN870379, EF143887, EF143856, EF624262, FJ626591, HQ260815. Arcangelisia flava (L.) Merr., cult. Malaysia, F. Jacques 26 (P), FJ603109, JN051744, JN051810, EF624269, HQ260763, EU526980. Coscinium fenestratum Colebr., Sri Lanka, Chase 17404 (K), FJ603111, JN051757, JN051823, JN051706, FJ026479, FJ026419. 


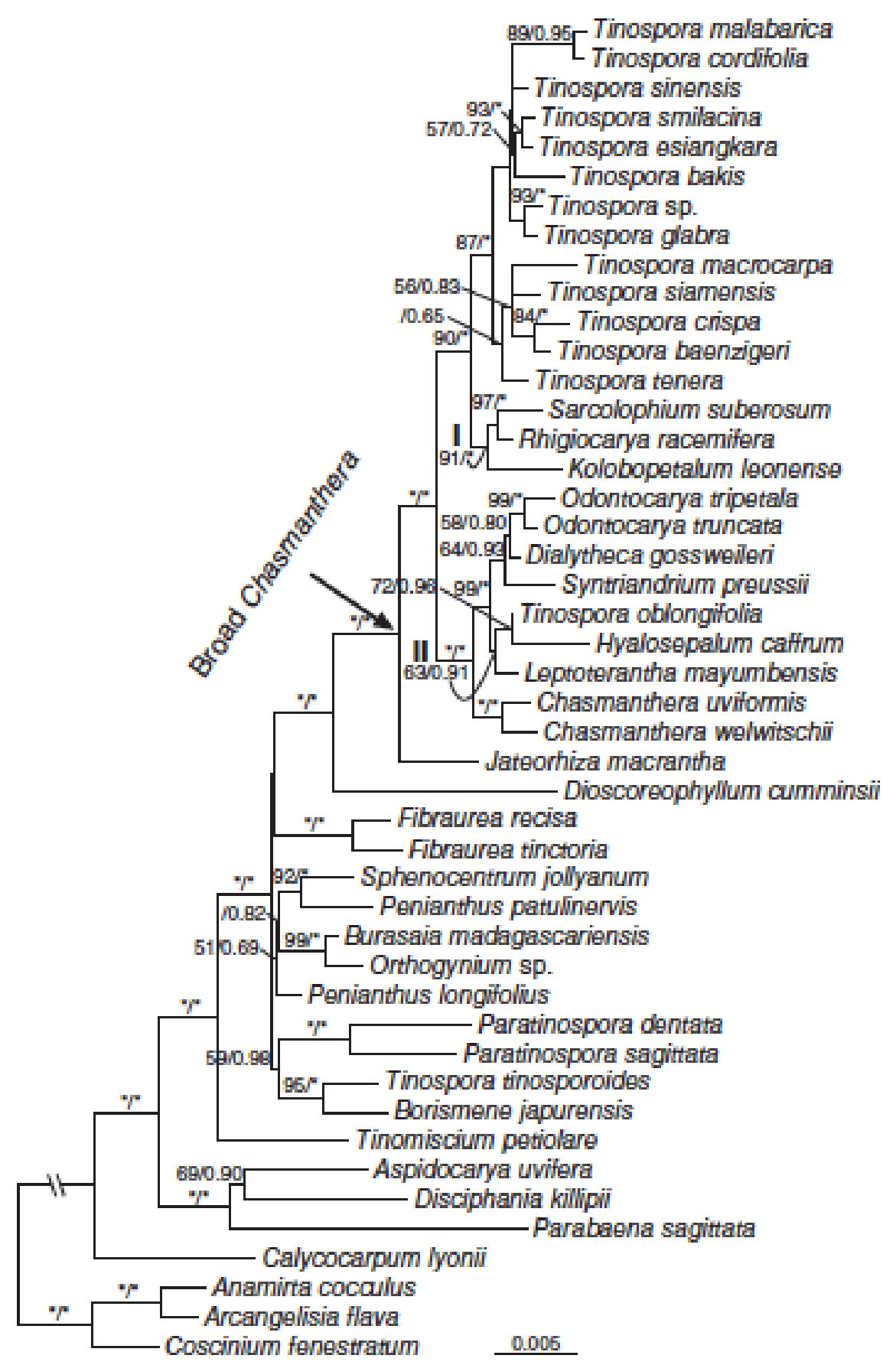

Fig. 1. ML tree inferred from the cpDNA dataset. Numbers above branches are bootstrap values (BS $\geq 50 \%)$ and posterior probabilities ( $\mathrm{PP} \geq 0.60)$. An asterisk $(*)$ indicates $\mathrm{BS}=100$ or $\mathrm{PP}=1.0$. 


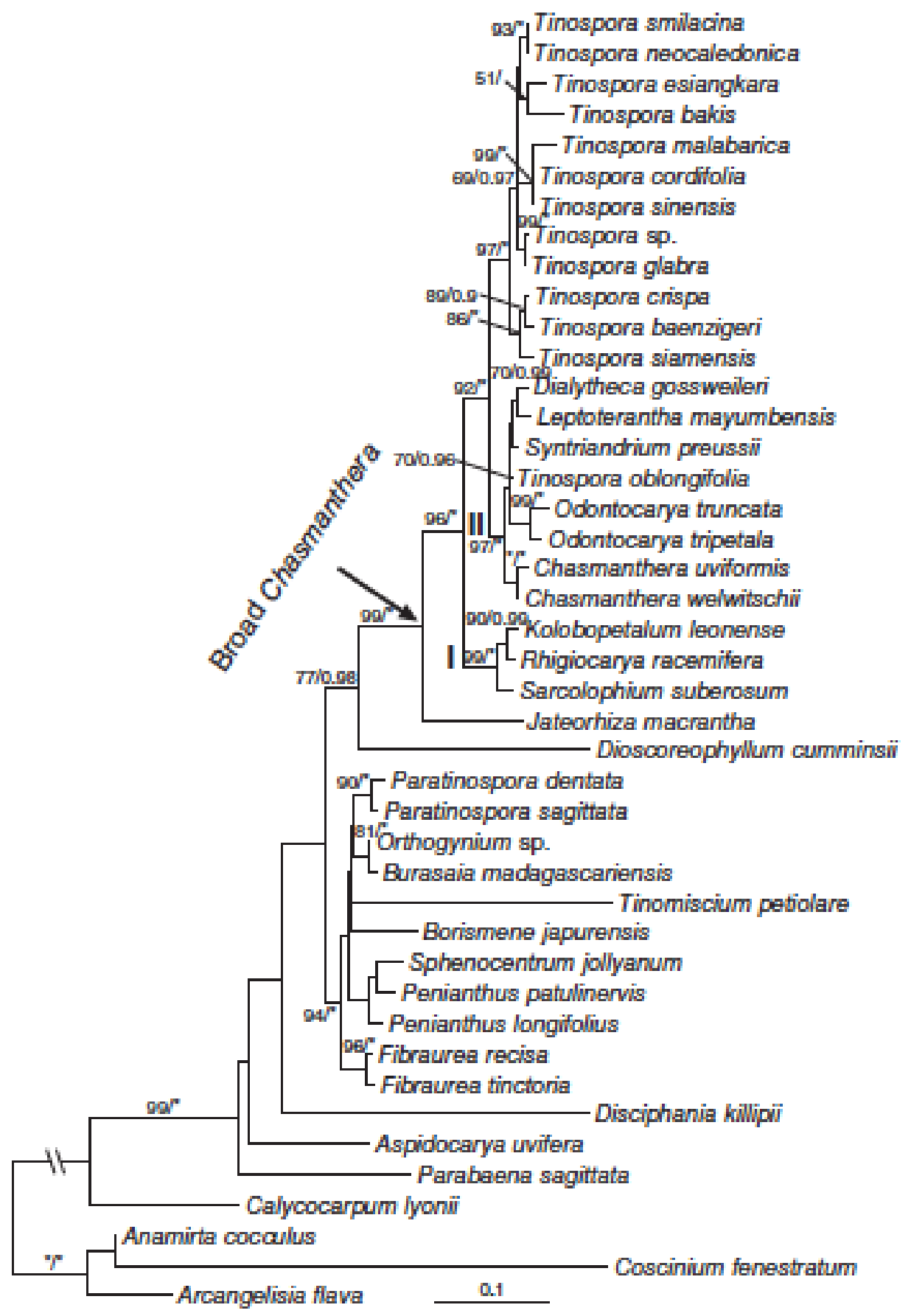

Fig. 2. ML tree inferred from the ITS dataset. Numbers above branches are bootstrap values (BS $\geq 50 \%$ ) and posterior probabilities $(\mathrm{PP} \geq 0.60)$. An asterisk $(*)$ indicates $\mathrm{BS}=100 \%$ or $\mathrm{PP}=1.0$. 


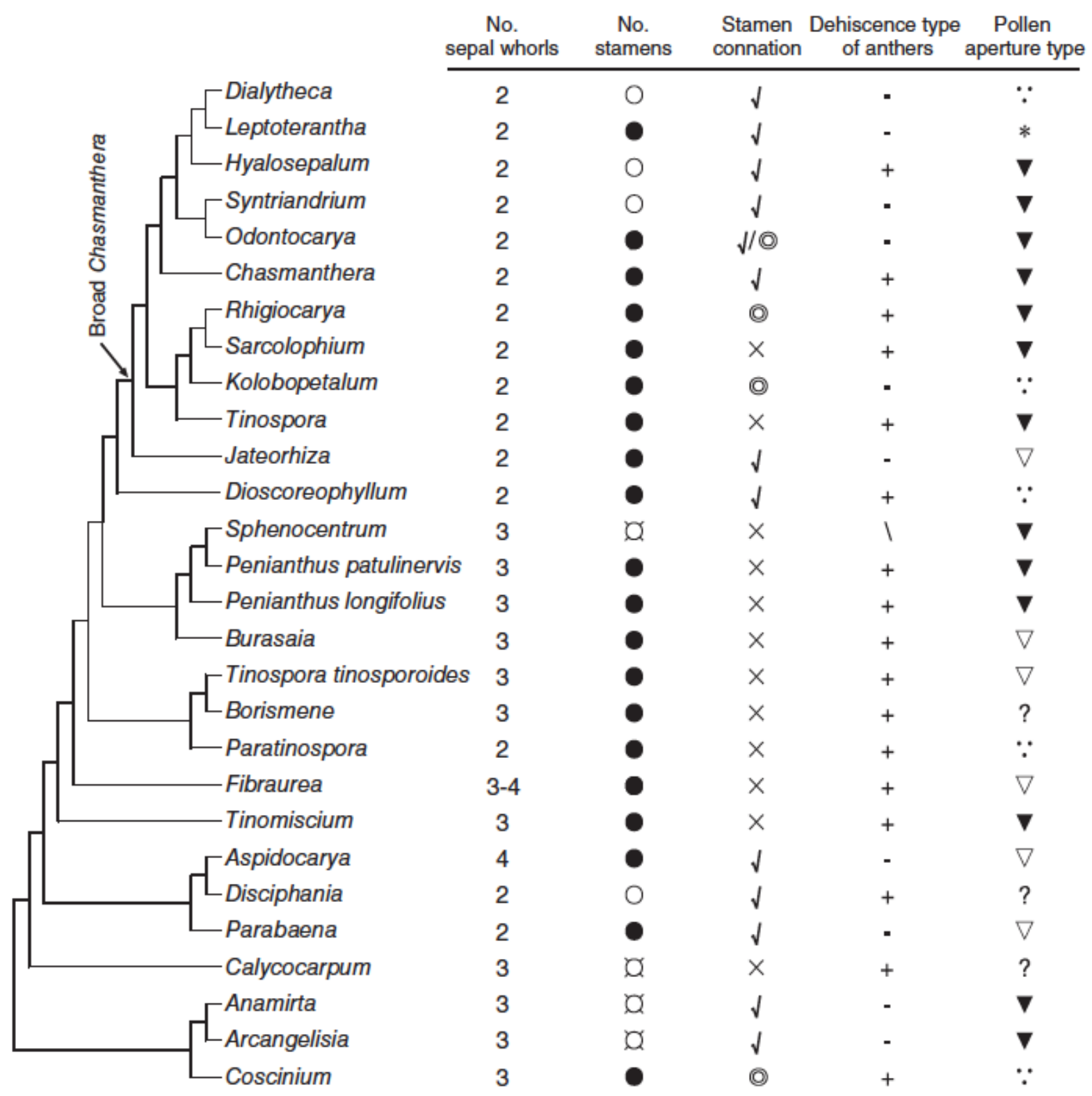

Fig. 3. Simplified ML tree generated from the combined cpDNA and ITS data showing the distribution of selected character states. Branches in bold indicate $\mathrm{BS} \geq 70 \%$ and $\mathrm{PP} \geq 0.95$. Characters are: number of sepal whorls $(2,3,4)$, number of stamens $(\mathrm{O}, 3 ; \bullet, 6 ; \alpha, \geq 9)$, stamen connation $(\AA \sim$, no; $\sqrt{ }$, yes; concentric circles, outer free and inner connate), dehiscence type of anthers (+, longitudinal; -, transversal; \, lateral), and pollen aperture type ( $\because$, triporate; $\nabla$, tricolpate; $\nabla$, tricolporate; $*$, 6-cryptoporate; ?, missing data). 


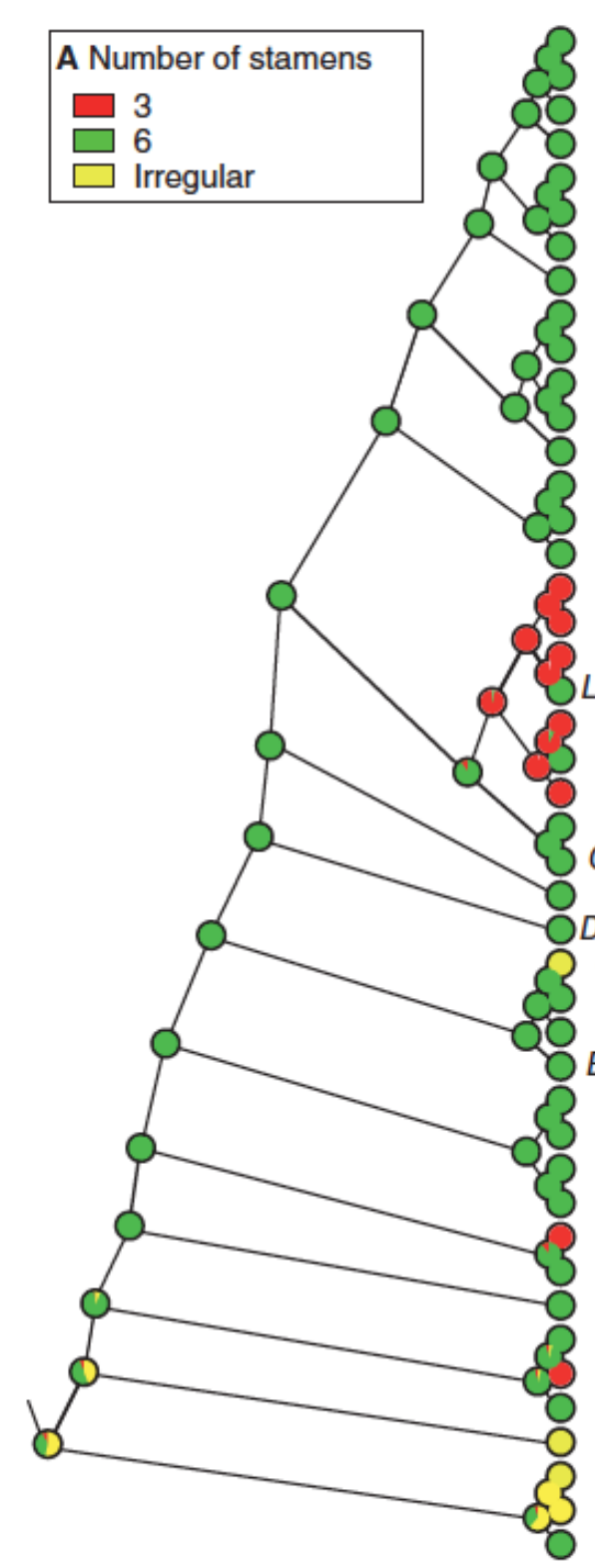

Tinospora neocaledonica Tinospora smilacina Tinospora esiangkara Tinospora bakis Tinospora malabarica Tinospora cordifolia Tinospora sinensis Tinospora glabra Tinospora baenzigeri Tinospora crispa Tinospora siamensis Tinospora macrocarpa Tinospora tenera Rhigiocarya racemifera Sarcolophium suberosum Kolobopetalum leonense Hyalosepalum caffrum Tinospora oblongifolia Dialytheca gossweileri Leptoterantha mayumbensis Odontocarya tripetala Odontocarya truncata Syntriandrium preussii Chasmanthera uviformis Chasmanthera welwitsch Jateorhiza macrantha Dioscoreophyllum cummins Sphenocentrum jollyanum Penianthus patulinervis Penianthus longifolius Burasaia madagascariensi Paratinospora dentata Paratinospora sagittata Tinospora tinosporoides Borismene japurensis Fibraurea recisa Fibraurea tinctoria Tinomiscium petiolare Aspidocarya uvifera Disciphania killipii Parabaena sagittata Calycocarpum lyonii Anamirta cocculus

Arcangelisia flava Coscinium fenestratum

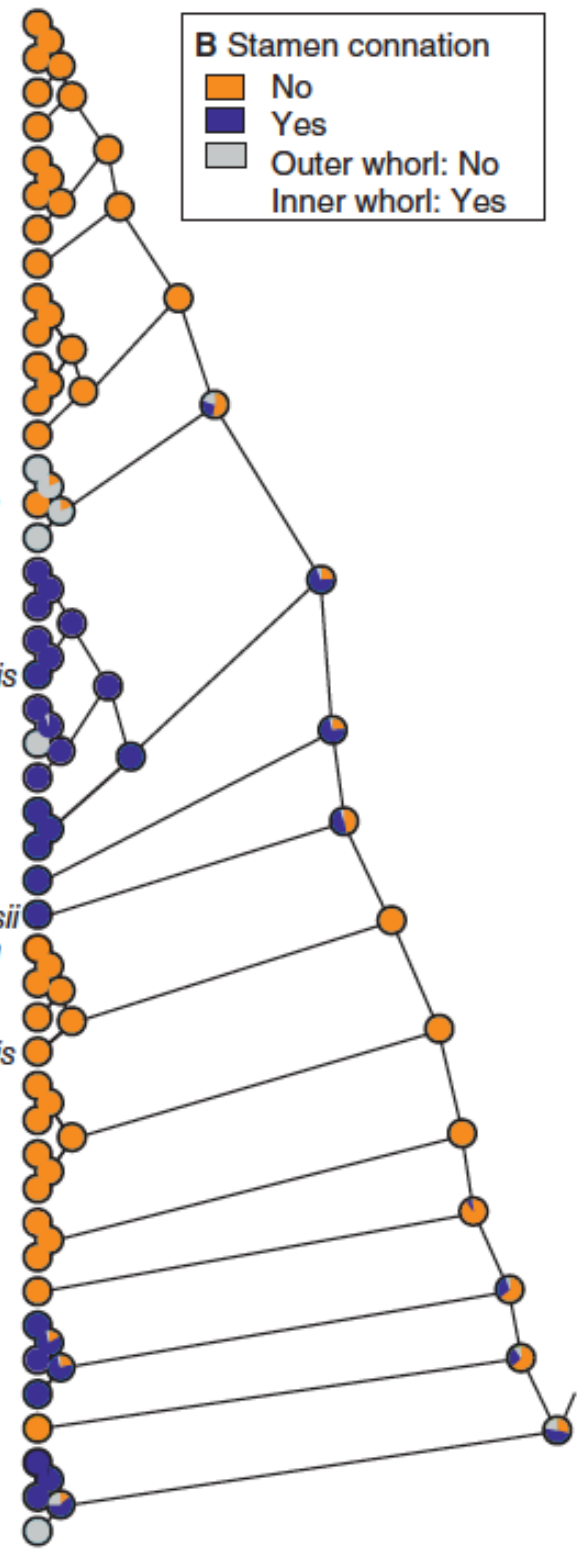

Fig. 4. Likelihood inference of character evolution in Burasaieae using Mesquite v.2.75 (Maddison \& Maddison, 2011). A, Number of stamens; B, Stamen connation. 


\begin{tabular}{lcc}
\hline & \multicolumn{2}{c}{ Age of the root } \\
\cline { 2 - 3 } Node & $101 \mathrm{Ma}$ & $80.14 \mathrm{Ma}$ \\
\hline 1 & $29.05(12.43-47.44)$ & $26.28(10,46-44,64)$ \\
2 & $28.57(22.67-34.76)$ & $26.67(20.51-32.49)$ \\
3 & $21.54(15.63-27.62)$ & $19.74(14.57-25.15)$ \\
4 & $17.53(12.02-23.39)$ & $15.85(10.72-21.34)$ \\
5 & $11.16(7.15-15.92)$ & $10.03(6.55-14.53)$ \\
6 & $9.71(5.84-14.61)$ & $8.72(5.27-12.75)$ \\
\hline
\end{tabular}

Tinospora baenzigeri

Tinospora crispa

Tinospora siamensis

Tinospora macrocarpa

Tinospora tenera

Tinospora malabarica

Tinospora cordifolia

- Tinospora esiangkara

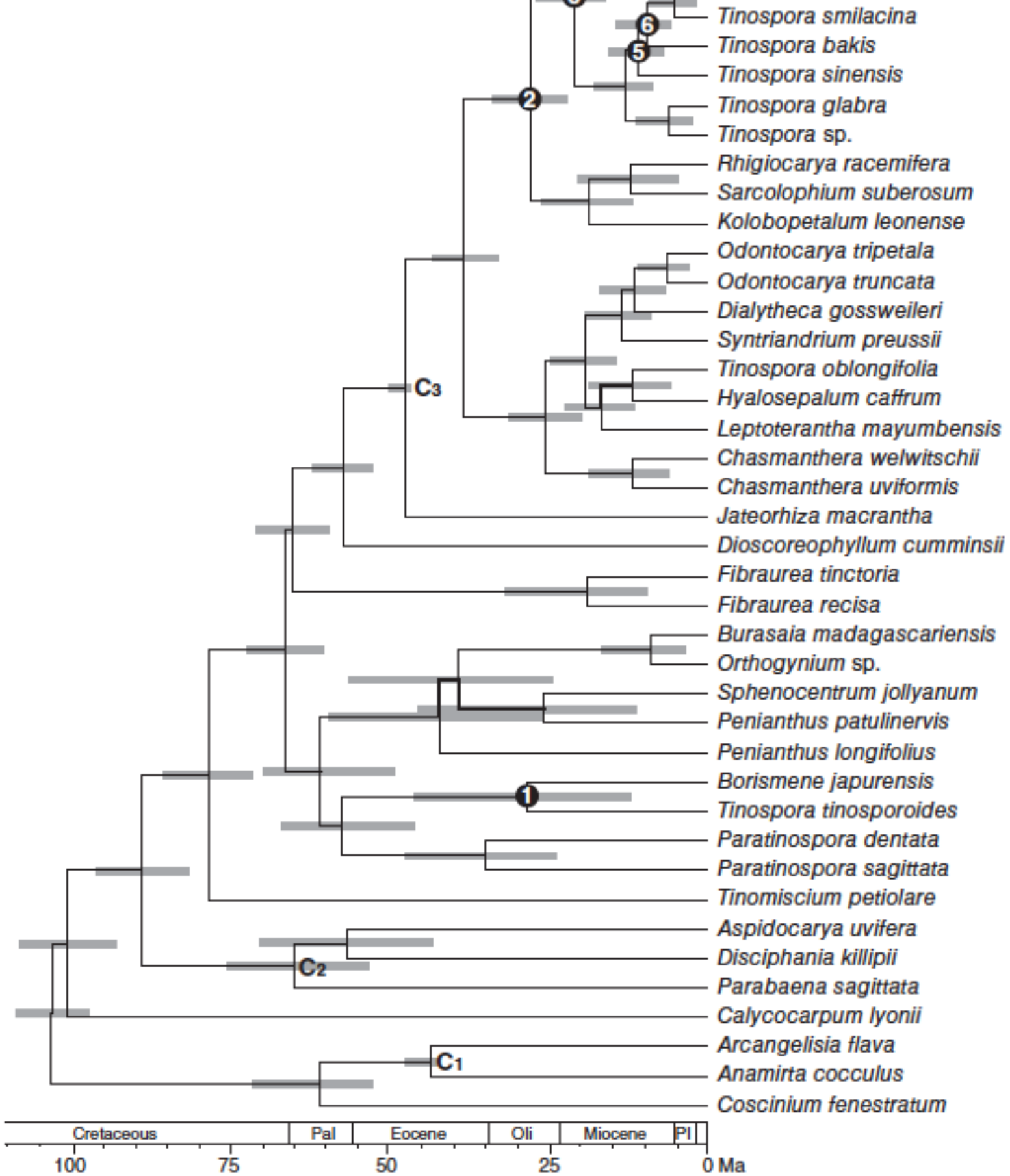

Fig. 5. Chronogram of Burasaieae based on the cpDNA data using BEAST with a 101 Ma maximum age for the root. Gray bars represent $95 \%$ highest posterior density intervals. The C1-3 indicate the locations of fossil calibration points. Nodes of interest were marked as 1-6. A comparison of estimated times for the nodes of interest is inserted in the upper left. $\mathrm{Pal}=$ Paleocene; Oli = Oligocene; $\mathrm{Pl}=$ Pliocene. 

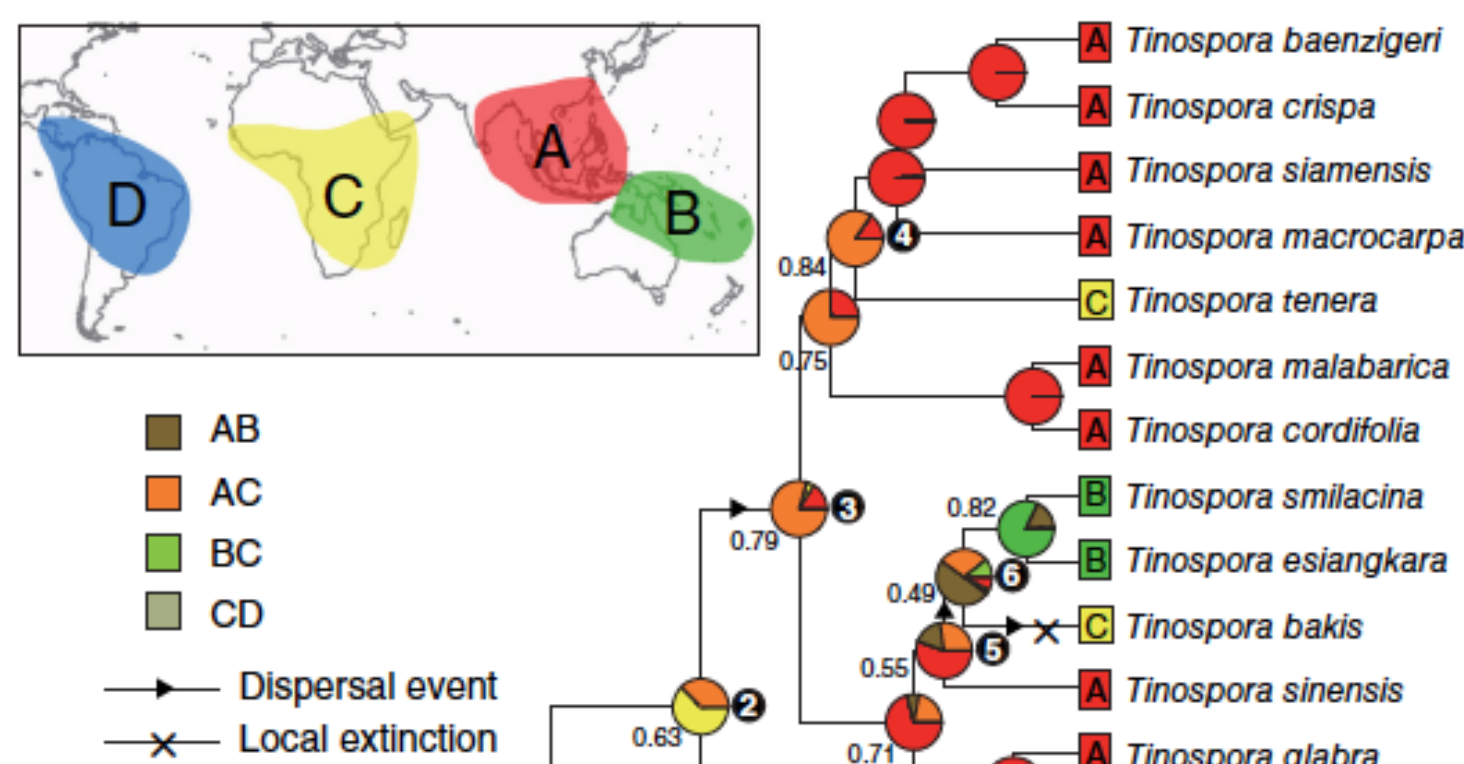

A Tinospora cordifolia

30.82 B Tinospora smilacina

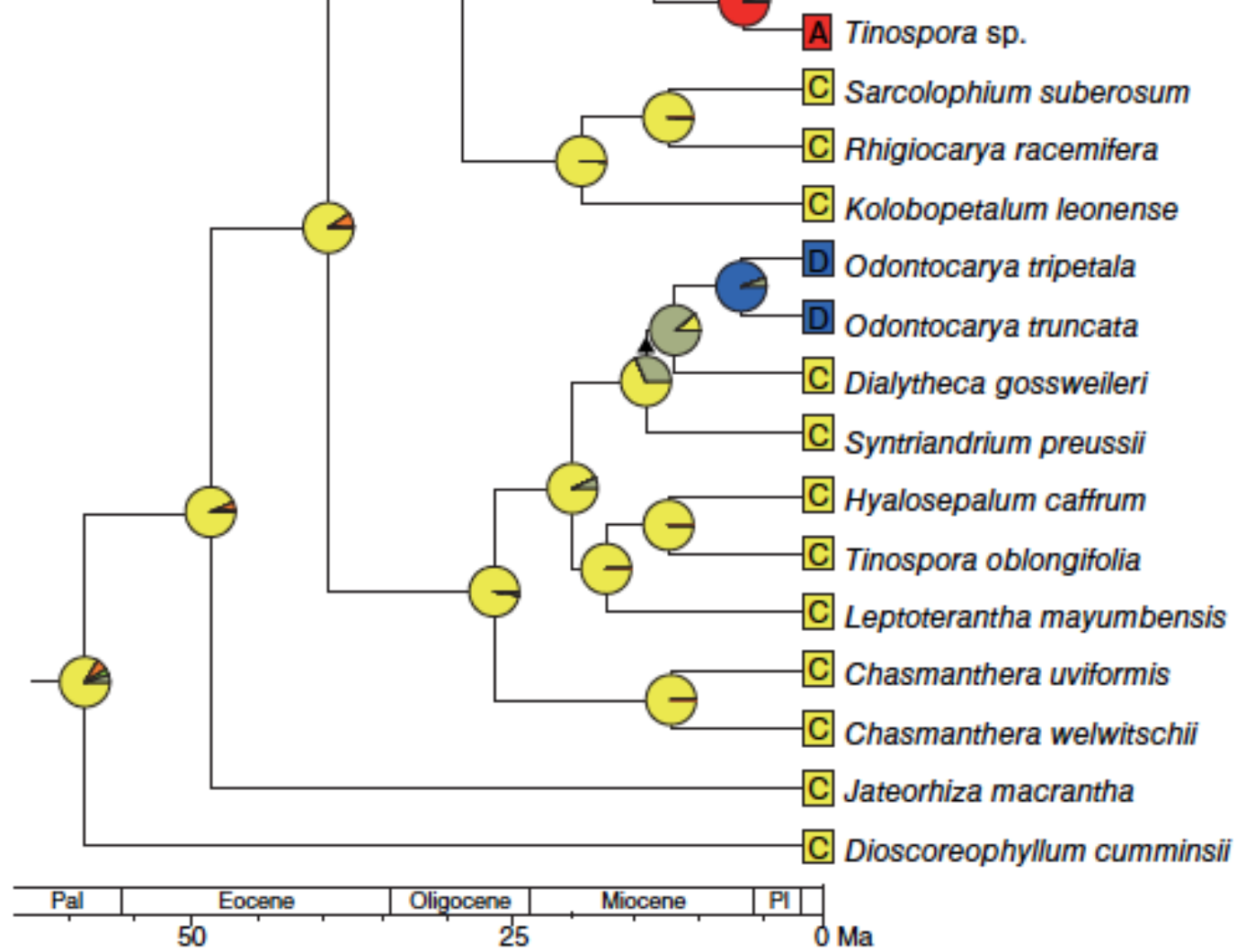

Fig. 6. Ancestral range reconstructions of the re-delimited Tinospora using BioGeoBEARS under the DEC model. Pie charts show the relative probabilities of alternative ancestral distributions, and numbers near the nodes indicate the highest ML probabilities. The node numbers correspond to those in Fig. 5 . Pal = Paleocene; Pl $=$ Pliocene. 